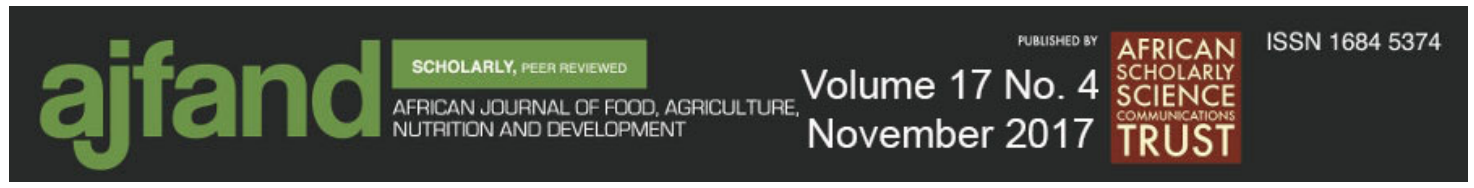

FARMERS' KNOWLEDGE OF THE BANANA (MUSA SP.) AGROFORESTRY SYSTEMS IN KIBOGA DISTRICT, CENTRAL UGANDA

\title{
Ssebulime $\mathbf{G}^{1}$, Kagezi $\mathbf{H G}^{2^{*}}$, Nyombi $\mathbf{K}^{1}$, Mpiira $\mathbf{S}^{2}$, Kucel $\mathbf{P}^{2}$, Byabagambi $\mathbf{S}^{3}$,
} Tushemereirwe $\mathrm{K} \mathrm{W}^{2}$, Kubiriba $\mathrm{J}^{2}$, Karamura $\mathrm{B} \mathrm{E}^{4}$ and $\mathrm{C} \mathrm{Stave}{ }^{5}$

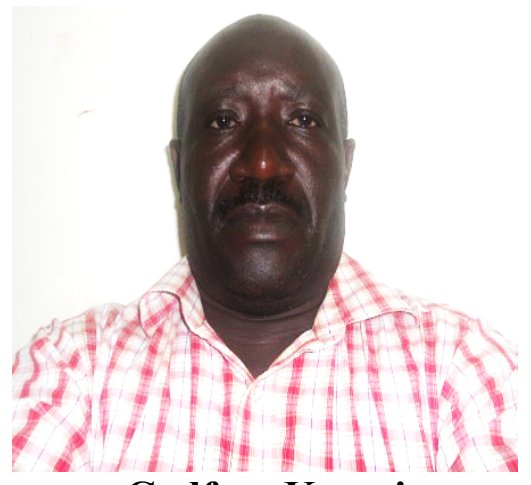

Godfrey Kagezi

*Corresponding author: gkagezi@gmail.com, kagezi@kari.go.ug

${ }^{1}$ Makerere University, College of Agriculture and Environmental Sciences, P.O Box 7062, Kampala, Uganda

${ }^{2}$ National Agricultural Research Organization (NARO), P.O. Box 295 Entebbe, Uganda

${ }^{3}$ United States Agency for international Development (USAID), P.O. Box 7007, Kampala, Uganda

${ }^{4}$ Bioversity International, Sub-Regional Office SSA, P.O. Box 24384, Kampala, Uganda ${ }^{5}$ Bioversity International, Parc Scientifique Agropolis II, 34397 Montpellier, France 


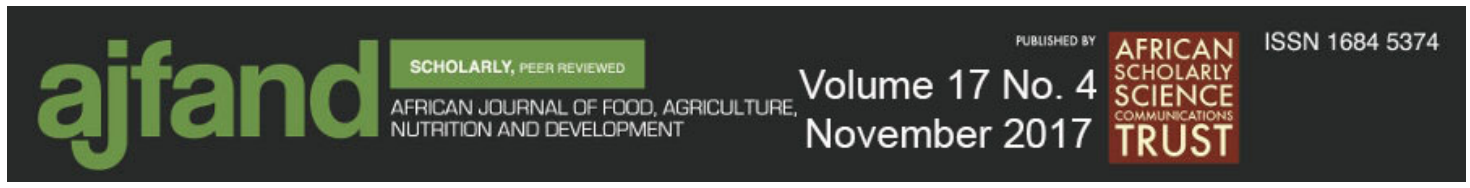

\section{ABSTRACT}

Banana is a major food and cash crop in Uganda, particularly in the central and southwestern regions. However, production is still below attainable yields and at the same time declining due to a number of reasons, with low soil fertility being paramount. Few farmers use inorganic fertilizers, with majority of them relying mainly on organic supplements including integration of trees/shrubs. However, trees and shrubs exist on banana farms in undefined numbers and composition, with no spacing and canopy management recommendations. Also, there is limited information on farmers' knowledge on these systems. A survey was, therefore, conducted on 70 randomly selected farms in Kiboga district, central Uganda to assess farmers' knowledge of, as well as identify trees and shrubs species and banana cultivars in their agro-ecologies. A total of 1,558 trees and shrubs belonging to 40 species and 21 families were recorded in the study area (52 trees/shrubs per banana plantation). These were dominated by Jackfruit, Artocarpus heterophyllus (15\%), Natal fig, Ficus natalensis (10\%), Albizia, Albizia coriaria (10\%) and mango, Mangifera indica (9\%). Further, 1,779 banana mats belonging to nine (9) cultivars and three (3) genome groups were observed growing underneath these four commonest tree species ( 2.6 banana mats per tree). The highest number of banana mats was observed growing underneath $F$. natalensis (54\%) and $A$. coriaria (42\%). Most (87\%) observed banana cultivars belonged to the cooking East African Highland Banana (Musa AAA-EAHB) and dominated by Ndibwabalangira (21\%). Farmers reported 25 benefits they derive from banana-trees/shrubs integration; with shade and firewood (38\%), as well as income and timber (35\%) being the main benefits reported. They also reported that the highest percentage of benefits was derived from $F$. natalensis $(44 \%)$ and $A$. coriaria $(32 \%)$. Of the four (4) most prevalent tree species, A. coriaria (100\%) and $F$. natalensis $(96 \%)$ were reported as good companion plant to bananas, whereas, A. heterophyllus (99\%) and M. indica $(97 \%)$ were regarded as bad companion plants. Farmers preferred a tree that allows light penetration (96\%), is compatible with bananas and other crops $(87 \%)$ and has easily decomposable leaves (83\%). Therefore, $F$. natalensis and A coriaria should be integrated in banana agrosystems for soil fertility improvement whereas; A. heterophyllus and $M$. indica be planted on farm boundaries. However, the best-bet spacing and pruning regimes for these trees should be determined to minimize the negative attributes as much as possible.

Key words: Albizia coriaria, Artocarpus heterophyllus, banana cultivars, benefits, companions, farmers' knowledge, Ficus natalensis, Mangifera indica, tree-species 


\section{INTRODUCTION}

Banana is an important staple food and income source for more than 10 million rural and urban Ugandans [1]. The crop also provides feed for animals, medicine, serves cultural roles as well as industrial uses. Despite its importance, production is still below the attainable yields $[2,3]$. Average highland bananas yields $\left(5-30 \mathrm{Mg} \mathrm{ha}^{-1} \mathrm{yr}^{-1}\right)$ are below the estimated potential yield of over $70 \mathrm{Mg} \mathrm{ha}^{-1} \mathrm{yr}^{-1}$ [4]. This is mainly attributed to abiotic and biotic constraints with declining soil fertility being paramount $[5,6]$. This is more pronounced in the central compared to the southwestern part of the country [7].

Contrary to commercial banana production in most parts of the world, few Ugandan banana farmers use mineral fertilizers to replenish soil nutrient stocks [8]. Instead, they rely on organic supplements [4], including integration of banana and trees [9, 10]. However, poor tree choice and canopy management practices may promote competition for light, nutrients, space and moisture, among others [11]. In addition, these systems are yet to be fully quantified and there are no recommendations on how to intercrop the bananas and the trees [3]. Trees and shrubs exist in infinite numbers and compositions on banana farms with no proper spacing and sequencing as well as canopy management recommendations. There is also limited information on farmers' knowledge on agroforestry which poses serious challenges to the proper use of particular tree species for soil fertility improvement [12]. Such information is vital since socio-cultural settings are known to influence adoption and valuation of agro-forestry systems [13]

This study was, therefore, conducted in Lwamata sub-county, Kiboga district, central Uganda to: i) identify tree/shrub species and banana cultivars on smallholder farms, and ii) assess farmers' knowledge on the benefits of tree/shrubs-banana integration, and iii) determine the criteria used by farmers to classify a tree/shrub as 'good' or 'bad' neighbor to bananas.

\section{MATERIALS AND METHODS}

\section{Description of the study area}

The study was conducted in Kisweeka parish, Lwamata sub-county, Kiboga District, central Uganda in 2012. The district lies between $1^{\circ} 30^{\text {ee }} \mathrm{N}$ and $32^{\circ} 14^{\text {ee }} \mathrm{E}$ at $1000-1200$ m.a.s.1 [14]. Farming is the major economic activity and about $80 \%$ of the district labor force is engaged in agricultural activities. The most predominant crops grown are bananas, beans, coffee, cassava, maize and sweet potatoes [15].

\section{Sample selection and data collection}

Lwamata sub-county was purposively selected for the study because bananas are predominantly intercropped with trees and/or shrubs [16]. Names of all the parishes in Lwamata sub-county were written on pieces of papers singly, folded and Kisweeka parish picked randomly. Then, the names of all villages in Kisweeka parish were written singly on pieces of papers and five villages were randomly selected, namely - Kisweeka, Kiryamuddo, Nabuzaana, Buyira and Nabyoto. A pretested questionnaire eliciting farmers' knowledge on the banana agro-forestry system was administered to 70 randomly selected farming households. From these, 30 households ( 6 per village) were 


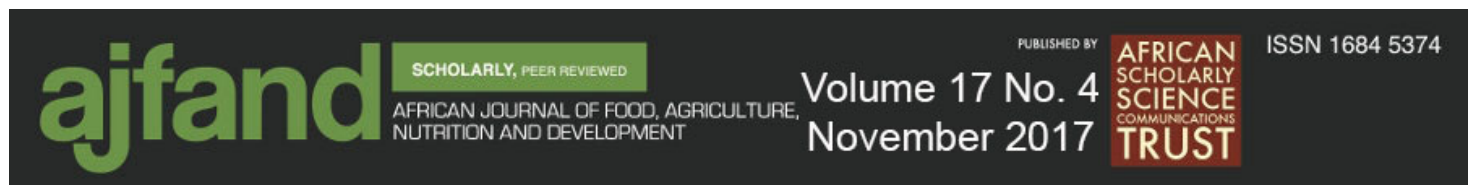

randomly selected for tree and banana profiling. In each banana plot, all the trees and shrubs taller than $3 \mathrm{~m}$ in a $10 \mathrm{x} 10 \mathrm{~m}$ quadrant were identified at species level, counted and recorded [16]. In addition, the four (4) most prevalent tree/shrub species were identified and banana mats underneath identified by cultivar, counted and recorded.

Cultivar proportions were then determined by measures of cultivar abundance and explained by determining variety richness (number) and evenness (distribution). The cultivar richness and evenness were summarized using the cultivar diversity indices based on Shannon-Wiener diversity index [17].

$$
\text { Diversity Index (DI) }=-\sum_{i=1}^{s} \alpha i, \ln \alpha i
$$

Where; $\quad \mathrm{s}=$ number of cultivars

$\alpha i=$ the proportion of individuals or the abundance of the $i^{\text {th }}$ cultivar; expressed as a proportion of the total sample

$\ln =$ natural logarithm

\section{Data analysis}

Data analyses were done in SAS v. 9.1 for Windows [18]. Descriptive statistics were used to obtain means, standard deviations and frequencies, and presented in tabular and graphic forms. The numbers of banana mats per cultivar as well as the number and species diversity of banana cultivars underneath four (4) most prevalent tree species were compared using a Chi square test.

\section{RESULTS}

\section{Tree/shrub species and banana cultivars observed}

Results showed that 1,558 trees/shrubs belonging to 40 species and 21 families were recorded in the study area (Table 1). This gives an average of 52 trees/shrubs per banana plantation. The four (4) most prevalent tree species observed were: - Artocarpus heterophyllus (15\%), Ficus natalensis (10\%), Albizia coriaria (10\%) and Mangifera indica (9\%). The dominant families were Fabaceae (23\%) and Moraceae (20\%) (Table $1)$.

Furthermore, 1,779 banana mats belonging to nine (9) cultivars and three (3) genome groups were observed growing underneath the four most prevalent tree species. Most $(87 \%)$ of the observed banana cultivars belonged to the cooking East African Highland Banana (Musa AAA-EAHB). The number of observed banana mats varied significantly $\left(\chi^{2}=405.07, \mathrm{P}=<0.0001\right)$ across the cultivars; with the highest recorded for Ndibwabalangira (21\%) (Table 2).

Results showed that the number of banana mats varied significantly $\left(\chi^{2}=1565.77, \mathrm{P}=<\right.$ $0.0001)$ among the four most prevalent tree species. The highest number of mats was observed underneath $F$. natalensis (54\%) and A. coriaria (42\%); whereas, the lowest $(0.9 \%)$ was underneath $A$. heterophyllus. The species diversity of the bananas observed 


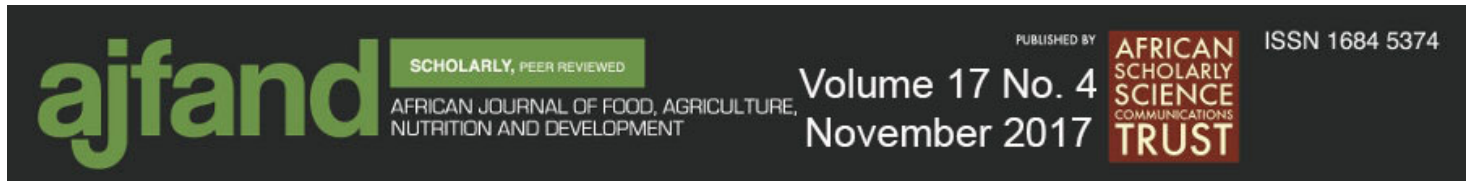

underneath the four (4) most prevalent tree species was not significantly different across the tree species $\left(\chi^{2}=0.2574, \mathrm{P}=0.9678\right)$. It was highest (2.09) underneath $F$. natalensis and lowest (1.34) underneath A. heterophyllus (Table 3).

F. natalensis and A. coriaria canopies supported all the nine (9) banana cultivars observed. Kibuzi and Mpologoma were not observed underneath $M$. indica and $A$. heterophyllus. Ndibwabalangira was the most abundant banana cultivar observed underneath $F$. natalensis (240 mats) and A. coriaria canopies (137 mats) whereas, Kayinja was the most prevalent underneath $M$. indica (20 mats) and A. heterophyllus canopies (6 mats; fig. 1).
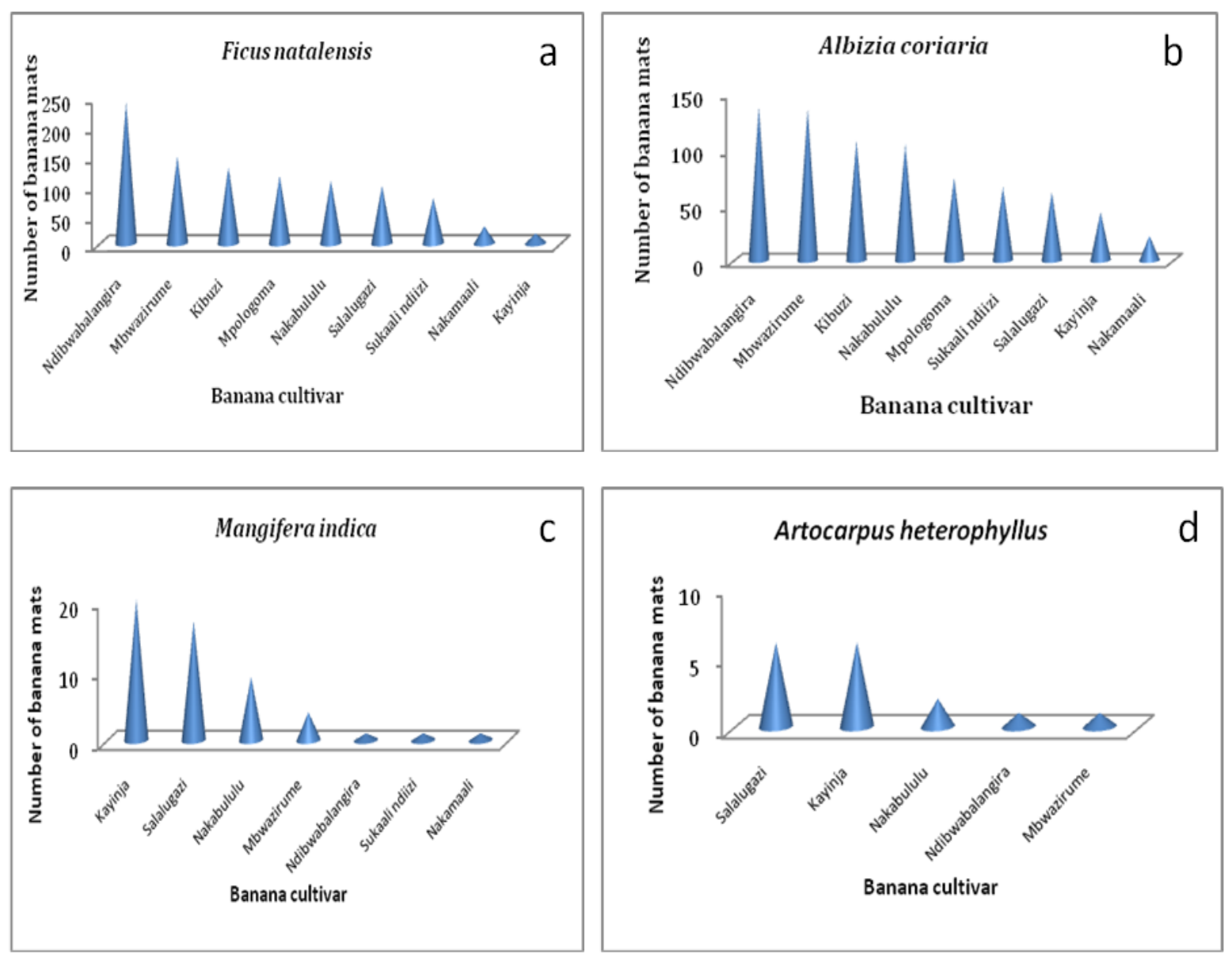

Figure 1: Occurrence of banana cultivars underneath the four most prevalent tree species; Ficus natalensis (A), Albizia coriaria (B), Mangifera indica (C) and Artocarpus heterophyllus (D) in banana plots of Kiboga district, Uganda

Farmers' knowledge of the benefits accruing from tree/shrubs-banana integration Responses from the 70 farmers interviewed showed that 25 benefits were derived from trees that are inter-planted with bananas. The highest proportion reported that trees provide shade (38\%) and play an important role in soil fertility improvement $(25 \%)$. On the other hand, source of income was reported by the highest proportion (35\%) of farmers 


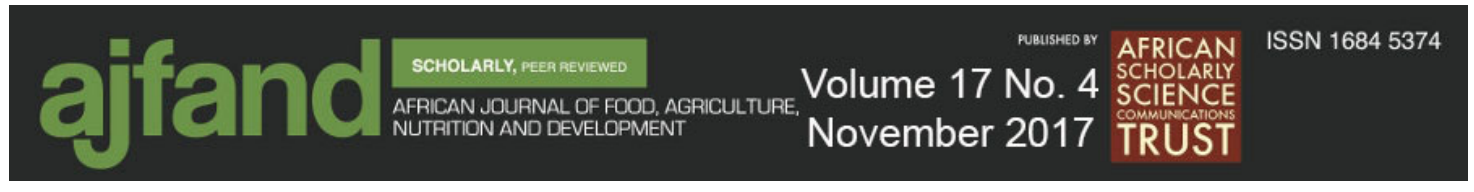

as the most important service accruing from trees, whereas, firewood (38\%), timber $(35 \%)$ and, food and fodder $(30 \%)$ were the most important products derived from trees. Farmers reported that the highest percentage of benefits were from F. natalensis (44\%) and $A$. coriaria ( $32 \%$; Table 4$)$.

\section{Farmers' knowledge and definition of a good or bad companion tree/shrub species} to bananas

All farmers (100\%) reported Albizia coriaria, Azadirachta indica, Calliandra calothyrsus, F. sycomorus and Sesbania sesban as good companion plants to bananas. Acacia hockii, Eucalyptus grandis and Pinus caribaea were regarded as bad companion plants to bananas. Of the four (4) most prevalent tree species, farmers reported A. coriaria $(100 \%)$ and $F$. natalensis $(96 \%)$ as good companion plants to bananas, whereas, A. heterophyllus (99\%) and M. indica (97\%) were regarded as bad companion plants to bananas (Table 5).

Most farmers (96\%) reported ability of the tree canopy to allow light penetration, the presence of bananas or other crops underneath tree canopy $(87 \%)$, and small and smooth leaves $(83 \%)$ as the criteria they use to classify a tree/shrub as good companion plants to bananas (Figure 2).

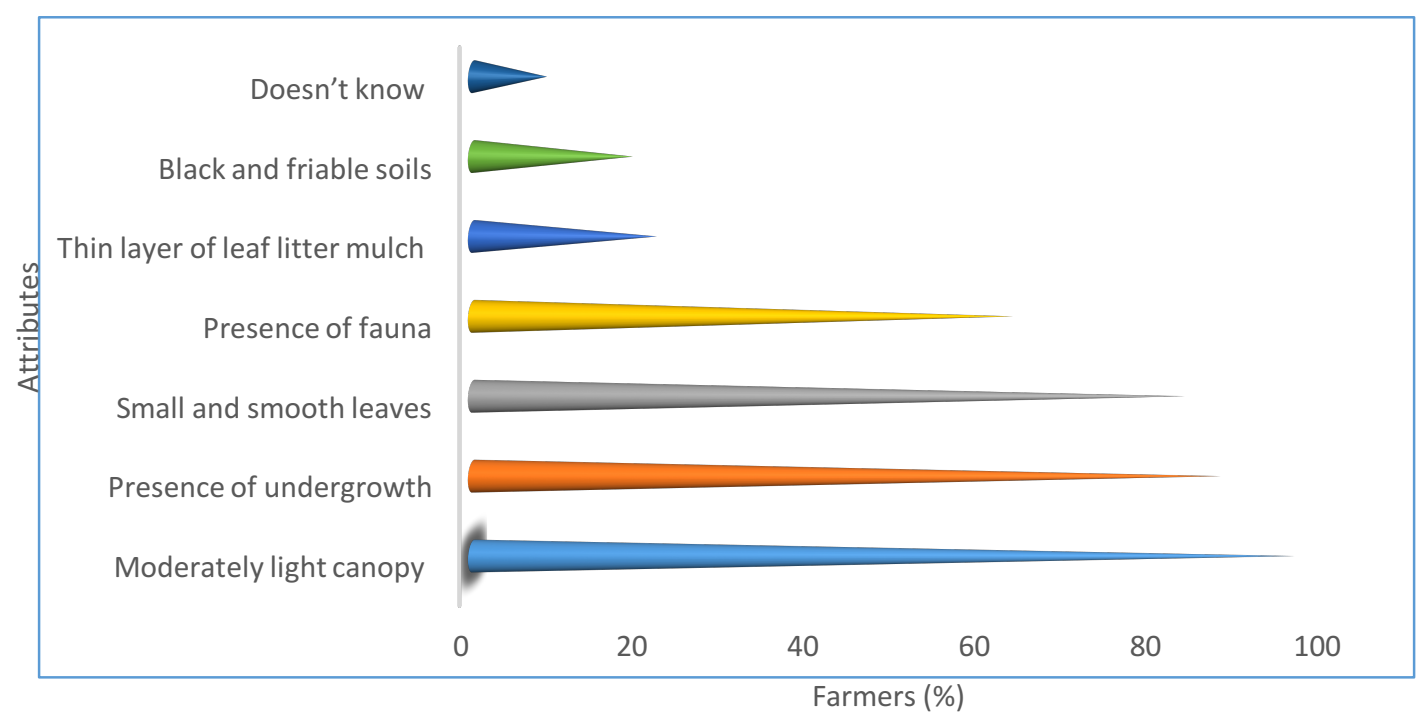

\section{Figure 2: Criteria used by farmers in Kiboga district, Uganda to classify a tree/shrub species as good companion plants to bananas}

Most farmers (97\%) reported thick canopy densities, large and coarse leaves (86\%) and no or few banana mats underneath their canopies $(79 \%)$ as the criteria they use to classify a tree/shrub as bad companion plants to bananas (Fig. 3). 

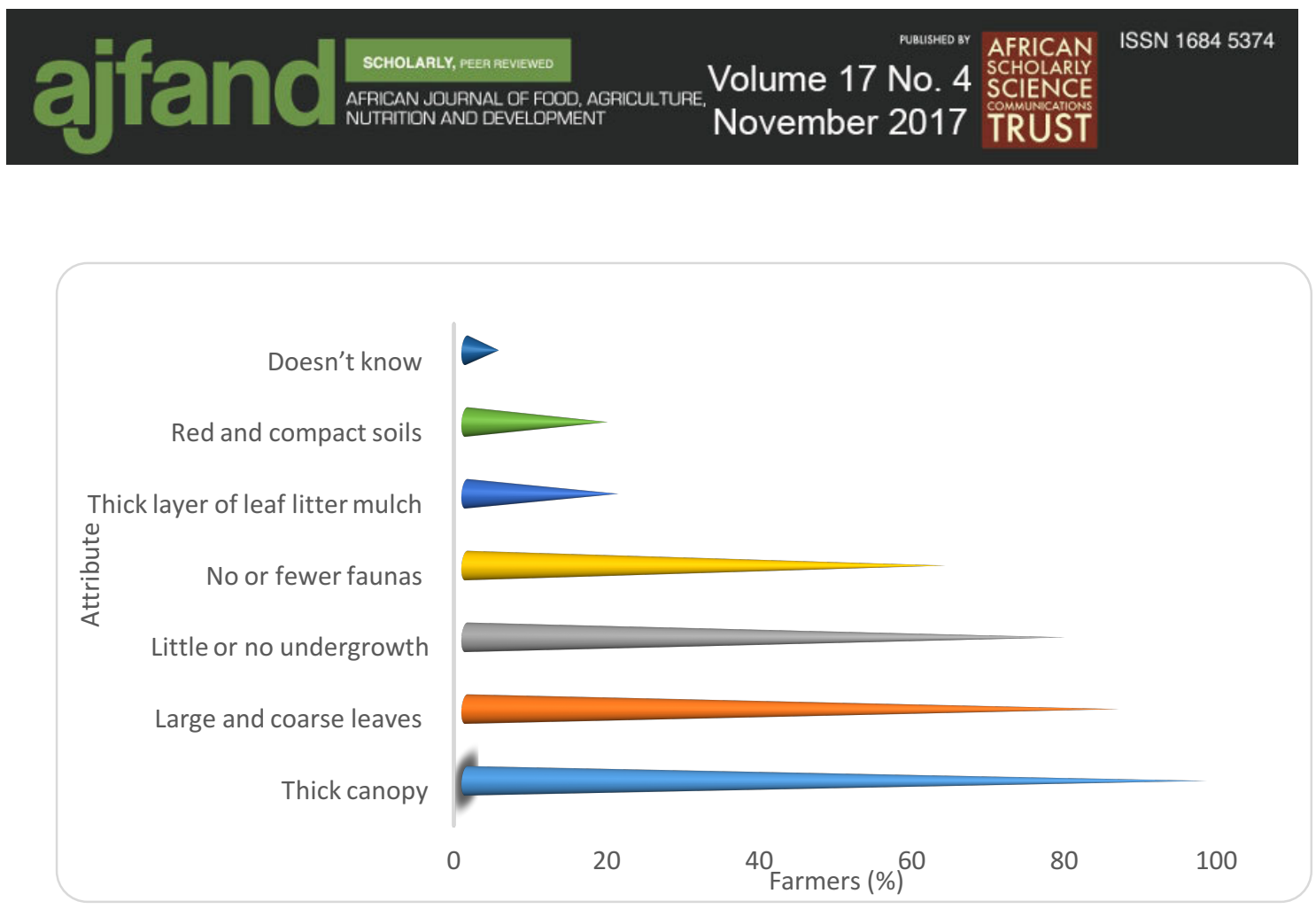

\section{Figure 3: Criteria used by farmers of Kiboga district, Uganda to classify a tree/shrub as bad companion plants to bananas}

\section{DISCUSSION}

Traditionally, farmers in Uganda often deliberately retain, maintain and plant trees with their bananas $[9,16]$. Results from this study showed a high density of trees/shrubs in the study area, with an average of 52 tree/shrubs per banana plot. This concurs with other studies in central and eastern Uganda [19, 20]. Similarly, the 40 tree/shrub species observed in this study are in line with work done by Kiyingi and Gwali [19] and Isabirye [20]. In the present study, Artocarpus heterophyllus, Ficus natalensis, Albizia coriaria and Mangifera indica were dominant. In addition, these tree/shrub species were fairly diverse with a Shannon-Weaver index of 2.85 , a result that was also reported by Isabirye [20] in eastern Uganda. Few banana mats were generally observed underneath the four (4) commonest tree species (2.6 mats per tree species) which tallies with observations by Dold et al. [21]. This could be a deliberate action by farmers to reduce competition for available resources. But this may offer opportunities, where densities can be increased, coupled with other supplemental nutrient sources and improved canopy management. In Uganda, farmers usually grow a range of cultivars (12-23) in their banana plots for food security, risk aversion and to derive a range of benefits [7,22].

The East African Highland Banana (Musa AAA-EAHB) dominated the genomic groups observed, emphasizing their importance in central Uganda [7, 6]. This genomic group constitutes more than $70 \%$ of all the bananas grown in Uganda, contributing to the food security and income of both rural and urban population, particularly in the central and south-western Uganda. The banana cultivars in this study were dominated by Ndibwabalangira and Mbwazirume, agreeing with farmers' responses as reported by Mpiira et al. [16]. The highest number of banana mats and species diversity were observed underneath $F$. natalensis and $A$. coriaria whereas, the lowest underneath $A$. 
heterophyllus and $M$. indica. Kayinja (Musa ABB) dominated the banana cultivars observed underneath $A$. heterophyllus and $M$. indica probably due to their ability to survive under more stressful conditions (poor quality leaf litter / soil fertility, thick canopy and reduced radiation penetration) as compared to the cooking East Africa highland bananas.

Farmers in Uganda have been integrating trees and crops for decades [23] due to a number of reasons. In this study, farmers demonstrated knowledge of the advantages and disadvantages attached to the agro-forestry systems [24, 25]. They cited 25 functions/services/products derived from the trees inter-planted with bananas, which were in agreement with the findings by Tabuti [26]. Farmers ranked provision of shade and soil fertility improvement as the most important functions accruing from trees. This corroborates with other findings $[10,12,24]$. A coriaria, $F$. natalensis and $M$. indica were cited by farmers as the best for provision of shade, which agrees with other findings [25]. Farmers cited A. coriaria, S. sesban, F. natalensis, C. calothyrus and F. sycomorus as the most important trees for improving soil fertility, agreeing with Nyombi et al. [10].

Farmers considered income as the most important service provided by trees [19, 27, 28]. However, this is contrary to Tabuti [26] who reported that smallholder farmers in eastern Uganda attached limited importance to trees as a source of income. Fruit trees and $E$. grandis were reported by farmers as the most important tree species that provide income, which was in line with Tabuti [26] and Nyamukuru et al. [29]. Farmers also identified firewood and timber as the most important products they derive from trees [30, 31], with $E$. grandis cited as the most utilized tree species for firewood. On the other hand, $M$. lutea, A. coriaria and M. eminii were the most preferred species for timber $[32,33]$. Farmers cited $F$. natalensis and $A$. coriaria as having the highest number of functions/services/products delivered from them. This is in conformity with findings from other studies $[12,25]$. The fact that these two tree species are multipurpose partly explains why they are the most abundant as well as most preferred by farmers in the study area.

Farmers were able to identify trees/shrubs that are either 'good' or 'bad' companions to bananas and to other crop species [34]. Of the four most common tree species, farmers cited A. coriaria and F. natalensis as 'good' companions, whereas, A. heterophyllus and $M$. indica were cited as 'bad' companions to the bananas. However, despite being regarded as 'bad', these tree species are predominant in farmers' cropping systems [34].

The decision to deliberately plant and/or maintain a tree/shrub species by farmers depends on the desirable or undesirable traits associated with the goods and services these trees provide [35]. In this study, farmers reported six (6) critical criteria they consider when classifying a tree/shrub as 'good' or 'bad' companion to bananas. Canopy density was the most important criterion considered by farmers when classifying a tree/shrub as 'good' or 'bad' for bananas [36]. In addition, compatibility of the tree species with bananas and other crops as well as small, smooth and easily decomposable leaves were also prominently reported criterion used by farmers [37]. 


\section{CONCLUSION}

From this study the following conclusions can be made:

1. Farmers in Kiboga district plant or maintain trees on their farms. An average of 52 trees/shrubs per banana plot belonging to 40 species dominated by Artocarpus heterophyllus, Ficus natalensis, Albizia coriaria and Mangifera indica were observed.

2. The highest number of banana mats was observed underneath $F$. natalensis and A. coriaria, whereas; Ndibwabalangira and Mbwazirume dominated the cultivars observed.

3. Overall, farmers cited 25 benefits derived from trees; but the highest number of benefits was registered for $F$. natalensis and $A$. coriaria.

4. Of the four (4) most prominent tree species, F. natalensis and A. coriaria were cited by farmers as 'good' neighbors to bananas; which is not surprising given the high number of mats underneath whereas, A. heterophyllus and $M$. indica were referred to as 'bad' neighbors.

It is, therefore, recommended that: -

1. F. natalensis and A. coriaria be integrated more into banana agro-systems for shade and soil fertility improvement,

2. On the other hand, A. heterophyllus and M. indica be planted on boundaries for other products and benefits such as firewood and timber among others,

3. However, the best-bet spacing and pruning regimes for both tree species should also be determined in order to minimize the negative attributes as much as possible.

\section{ACKNOWLEDGEMENT}

The authors are deeply grateful to the Austrian Development Agency for the research grant to Bioversity and partners to undertake this research. They also thank the farmers of Kiboga district for participating in this research. 


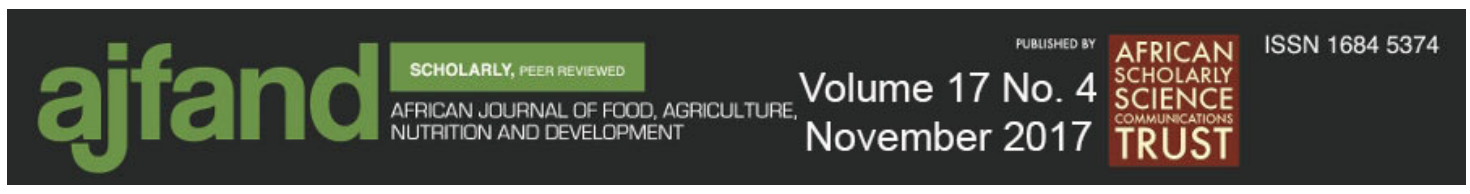

Table 1: Tree and shrub species observed in the banana cropping systems of Lwamata sub-county, Kiboga district, Uganda

\begin{tabular}{|c|c|c|c|c|c|c|}
\hline Family name & Scientific name & English name & $\begin{array}{l}\text { Local name } \\
\text { (luganda) }\end{array}$ & $\%$ & No. & Rank \\
\hline Moraceae & $\begin{array}{l}\text { Artocarpus } \\
\text { heterophyllus }\end{array}$ & Jackfruit tree & Fenensi & 15.3 & 239 & 1 \\
\hline Moraceae & Ficus natalensis & Natal fig & Mutuba & 10.2 & 159 & 2 \\
\hline Fabaceae & Albizia coriaria & Albizia & Mugavu & 10.0 & 155 & 3 \\
\hline Anacardiaceae & $\begin{array}{l}\text { Mangifera } \\
\text { indica }\end{array}$ & Mango & Muyembe & 9.2 & 143 & 4 \\
\hline Bignoniaceae & $\begin{array}{l}\text { Markhamia } \\
\text { lutea }\end{array}$ & $\begin{array}{l}\text { Bell Bean Tree, } \\
\text { Nile Tulip Tree }\end{array}$ & Musambya & 8.2 & 127 & 5 \\
\hline Fabaceae & $\begin{array}{l}\text { Calliandra } \\
\text { calothyrsus }\end{array}$ & Calliandra & Kaliyandula & 6.7 & 104 & 6 \\
\hline Rhamnaceae & $\begin{array}{l}\text { Maesopsis } \\
\text { eminii }\end{array}$ & Umbrella tree & Musizi & 6.6 & 103 & 7 \\
\hline Euphorbiaceae & Jatropha curcas & Jatropha & Kilowa & 5.6 & 87 & 8 \\
\hline Caricaceae & Carica papaya & Pawpaw/papaya & Mapapaali & 4.0 & 63 & 9 \\
\hline Lauraceae & $\begin{array}{l}\text { Persea } \\
\text { americana }\end{array}$ & Avocado pear & Vvakedo & 3.8 & 59 & 10 \\
\hline Fabaceace & $\begin{array}{l}\text { Leucaena } \\
\text { leucocephala }\end{array}$ & Lead tree & Lucina & 3.5 & 54 & 11 \\
\hline Moraceae & $\begin{array}{l}\text { Ficus } \\
\text { sycomorus }\end{array}$ & Fig-mulberry & Mukunyu & 3.3 & 52 & 12 \\
\hline Moraceae & Ficus mucuso & Fig & Kabalira & 2.6 & 41 & 13 \\
\hline Moraceae & Milicia excels & Rock-elm & Muvule & 1.2 & 19 & 14 \\
\hline Myrtaceae & $\begin{array}{l}\text { Psidium } \\
\text { guajava }\end{array}$ & Guava & Mupeera & 1.2 & 19 & 14 \\
\hline Fabaceae & Sesbania sesban & Sesbania & $\begin{array}{l}\text { muzimbandege } \\
\text { ya }\end{array}$ & 1.1 & 17 & 15 \\
\hline Bignoniaceae & $\begin{array}{l}\text { Spathodea } \\
\text { campanulata }\end{array}$ & African tulip tree & Kifabakazi & 1.0 & 15 & 16 \\
\hline Fabaceae & Albizia zygia & $\begin{array}{l}\text { West African } \\
\text { Albizia }\end{array}$ & Nongo & 0.8 & 12 & 17 \\
\hline Moringaceae & $\begin{array}{l}\text { Moringa } \\
\text { oleifera }\end{array}$ & Moringa & Mulinga & 0.8 & 12 & 17 \\
\hline Euphorbiaceae & $\begin{array}{l}\text { Ricinus } \\
\text { comminis }\end{array}$ & Castor oil plant & Nsogasoga & 0.5 & 7 & 18 \\
\hline Myrtaceae & $\begin{array}{l}\text { Syzygium } \\
\text { cumini }\end{array}$ & Black plum & Jambula & 0.5 & 7 & 18 \\
\hline Rutaceae & Citrus sinensis & Sweet orange & Mucungwa & 0.4 & 6 & 19 \\
\hline Moraceae & Ficus ovate & Fig & Mukokowe & 0.4 & 6 & 19 \\
\hline Fabaceae & $\begin{array}{l}\text { Tamarindus } \\
\text { indica }\end{array}$ & Tamarind tree & mukooge & 0.4 & 6 & 19 \\
\hline Moraceae & $\begin{array}{l}\text { Antiaris } \\
\text { toxicaria }\end{array}$ & False iroko & Kirundu & 0.3 & 4 & 21 \\
\hline
\end{tabular}




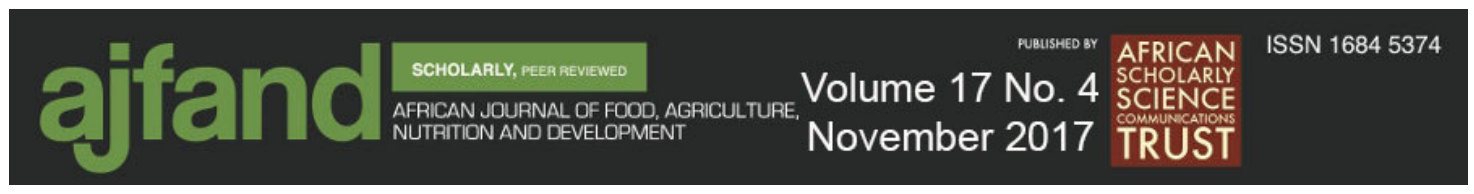

\begin{tabular}{|c|c|c|c|c|c|c|}
\hline Meliaceae & $\begin{array}{l}\text { Azadirachta } \\
\text { indica }\end{array}$ & Neem tree & Nnimu & 0.3 & 5 & 20 \\
\hline Fabaceae & $\begin{array}{l}\text { Erythrina } \\
\text { abyssinica }\end{array}$ & Lucy bean tree & jjirikiti & 0.3 & 4 & 21 \\
\hline Moraceae & $\begin{array}{l}\text { Ficus } \\
\text { exasperata }\end{array}$ & $\begin{array}{l}\text { Forest sandpaper } \\
\text { fig }\end{array}$ & Luwawu & 0.3 & 4 & 21 \\
\hline Pinaceae & Pinus caribaea & Caribbean pine & Payini & 0.3 & 4 & 21 \\
\hline Asteraceae & $\begin{array}{l}\text { Vernonia } \\
\text { amygdalina }\end{array}$ & Bitter leaf & Mululuza & 0.3 & 5 & 20 \\
\hline Mimosaceae & Acacia hockii & Wild acacia & Kasaana & 0.2 & 3 & 22 \\
\hline Annonaceae & $\begin{array}{l}\text { Annona } \\
\text { senegalensis }\end{array}$ & $\begin{array}{l}\text { Wild custard } \\
\text { apple }\end{array}$ & Kisitaferi & 0.2 & 3 & 22 \\
\hline Proteaceae & $\begin{array}{l}\text { Grevillea } \\
\text { robusta }\end{array}$ & Silky oak & Kalivaliyo & 0.2 & 3 & 22 \\
\hline Sapindaceae & $\begin{array}{l}\text { Sapindus } \\
\text { saponeria }\end{array}$ & Soap tree & Muyiki & 0.2 & 3 & 22 \\
\hline Rubiaceae & $\begin{array}{l}\text { Vangueria } \\
\text { apiculata }\end{array}$ & $\begin{array}{l}\text { Triangle flowered } \\
\text { wild medlar }\end{array}$ & Mutugunda & 0.2 & 3 & 22 \\
\hline Fabaceae & $\begin{array}{l}\text { Brachystegia } \\
\text { spiciformis }\end{array}$ & Zebrawood & Musasa & 0.1 & 1 & 23 \\
\hline Burseraceae & $\begin{array}{l}\text { Canarium } \\
\text { schweinfurthii }\end{array}$ & Incense tree & muwafu & 0.1 & 1 & 23 \\
\hline Myrtaceae & $\begin{array}{l}\text { Eucalyptus } \\
\text { grandis }\end{array}$ & Eucalyptus & Kalitunsi & 0.1 & 1 & 23 \\
\hline Fabaceae & $\begin{array}{l}\text { Gliricidia } \\
\text { sepium }\end{array}$ & Mouse killer & Muttamese & 0.1 & 1 & 23 \\
\hline Tiliaceae & Grewia mollis & - & Nkomakoma & 0.1 & 1 & 23 \\
\hline
\end{tabular}

Table 2: Ranks of banana cultivars growing underneath the four (4) most prevalent tree species in Kiboga district, Uganda

\begin{tabular}{lllccc}
\hline Cultivar name & Genome group & Use group & Percentage & Number & Rank \\
\hline Ndibwabalangira & AAA-EAHB & Cooking & 21.3 & 379 & 1 \\
Mbwazirume & AAA-EAHB & Cooking & 16.2 & 288 & 2 \\
Kibuzi & AAA-EAHB & Cooking & 13.3 & 237 & 3 \\
Nakabululu & AAA-EAHB & Cooking & 12.5 & 222 & 4 \\
Mpologoma & AAA-EAHB & Cooking & 10.6 & 189 & 5 \\
Salalugazi & AAA-EAHB & Cooking & 10.2 & 182 & 6 \\
Sukaali ndiizi & AAB & Dessert & 8.1 & 144 & 7 \\
Kayinja & ABB & Beer & 4.8 & 86 & 8 \\
Nakamaali & AAA-EAHB & Cooking & 2.9 & 52 & 9 \\
\hline
\end{tabular}




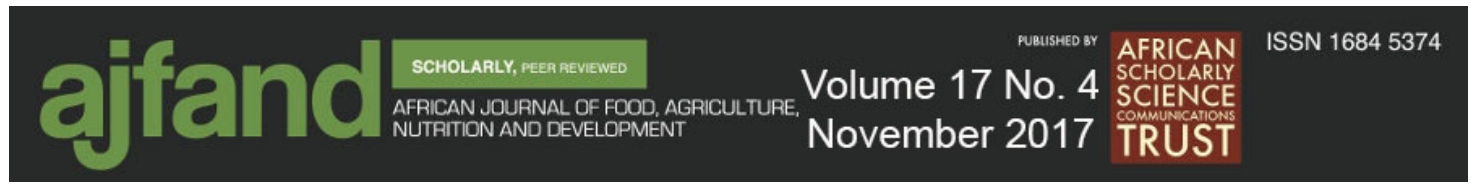

Table 3: Comparison of diversity of banana growing underneath the four most prevalent tree species in banana agro-systems of Kiboga district, Uganda

\begin{tabular}{llc}
\hline Trees species & Local name (Luganda) & Diversity index \\
\hline Ficus natalensis & Mutuba & 2.09 \\
Albizia coriaria & Mugavu & 2.02 \\
Mangifera indica & Muyembe & 1.45 \\
Artocarpus heterophyllus & Fenensi & 1.34 \\
$\chi^{2}$ & & 0.2574 \\
P value & & 0.9678 \\
\hline
\end{tabular}




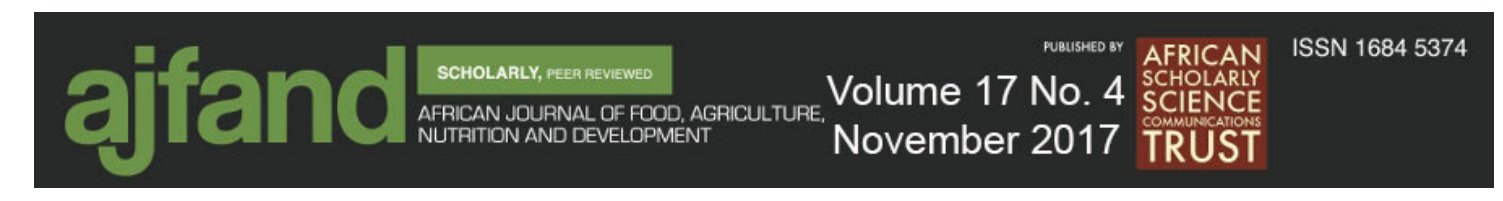

Table 4: Benefits derived from trees/shrub species as reported by farmers $(\mathbf{n}=\mathbf{7 0})$, Kiboga district, Uganda

\begin{tabular}{|c|c|c|c|c|c|c|c|c|c|c|c|c|c|c|c|c|c|c|c|c|c|c|c|c|c|c|c|}
\hline \multirow[t]{2}{*}{ Species } & \multicolumn{9}{|c|}{$\begin{array}{l}\text { Functions } \\
\end{array}$} & \multicolumn{3}{|c|}{ Services } & \multicolumn{13}{|c|}{ Products } & \multirow[t]{2}{*}{$\mathbf{N}$} & \multirow[t]{2}{*}{ Rank } \\
\hline & SF & SD & WB & EN & $\mathbf{R F}$ & LM & RM & $\mathbf{L F}$ & SS & IC & $\mathrm{CU}$ & GM & FW & TM & FD & FA & MD & $\mathrm{CH}$ & $\mathrm{BC}$ & $\mathbf{P F}$ & $\mathbf{P C}$ & $\mathrm{SC}$ & SB & SH & SFS & & \\
\hline Acacia hockii & & & & & 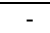 & - & & - & & & & 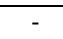 & 5.7 & & & 55.7 & 25.7 & 31.4 & - & 17.7 & 4.3 & - & - & - & - & 6 & 3 \\
\hline Albizia coriaria & 100.0 & 95.7 & 24.3 & - & - & - & - & - & - & 61.4 & - & - & 2.9 & 81.4 & - & - & - & 1.4 & - & 10.0 & - & - & - & - & - & 8 & 2 \\
\hline Albizia zygia & - & 40.0 & - & - & - & - & - & - & - & - & - & - & 10.0 & 34.3 & - & - & - & - & - & - & - & - & - & - & - & 3 & 6 \\
\hline Annona senegalensis & - & - & - & - & - & - & - & - & - & - & - & - & - & - & 20.0 & - & - & - & - & - & - & - & - & - & - & 1 & 8 \\
\hline Antiaris toxicaria & - & - & - & - & - & - & - & - & - & - & - & - & - & 25.7 & - & - & - & - & - & - & - & - & - & - & - & 1 & 8 \\
\hline Artocarpus heterophyllus & - & - & - & - & - & - & - & - & - & 92.9 & - & - & 8.6 & 12.9 & 100.0 & 68.6 & - & - & - & - & - & - & - & - & - & 5 & 4 \\
\hline Azadirachta indica & - & 11.4 & - & - & - & - & - & - & - & - & - & - & - & - & - & - & 78.6 & - & - & - & - & - & - & - & - & 2 & 7 \\
\hline Brachystegia spiciformis & - & - & - & - & - & - & - & - & - & - & - & - & 20.0 & - & - & 38.6 & - & - & - & - & - & - & - & - & 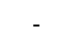 & 2 & 7 \\
\hline Calliandra calothyrus & 97.1 & - & - & - & - & - & - & - & 60.0 & - & - & - & 70.0 & - & - & 87.1 & - & - & - & - & - & 20.0 & 7.1 & - & - & 6 & 3 \\
\hline Canarium schweinfurthii & - & 2.9 & 10.0 & - & - & - & - & - & - & 12.9 & - & - & - & - & 65.7 & - & - & - & - & - & 7.1 & - & - & & - & 4 & 5 \\
\hline Carica papaya & - & - & - & - & - & - & - & - & - & 44.3 & - & - & - & - & 95.7 & 8.5 & - & - & - & - & - & - & - & - & - & 3 & 6 \\
\hline Citrus sinensis & - & - & - & - & - & - & - & - & - & 78.6 & - & - & - & - & 100.0 & - & - & - & - & - & - & - & - & - & - & 2 & 7 \\
\hline Erythrina abyssinica & 61.4 & - & - & - & - & - & - & - & - & - & 64.3 & - & - & 7.1 & - & - & 10.0 & - & - & - & - & - & - & - & - & 4 & 5 \\
\hline Eucalyptus grandis & - & - & 58.6 & - & - & - & - & - & - & 90.0 & - & - & 95.7 & 24.3 & - & - & - & - & - & 7.1 & - & 8.6 & - & - & - & 6 & 3 \\
\hline Ficus exasperate & - & 65.7 & - & - & - & - & - & - & - & - & - & - & - & 10.0 & - & - & - & - & - & - & - & - & - & - & - & 2 & 7 \\
\hline Ficus тисиso & 65.7 & 47.1 & - & - & - & - & - & - & - & - & - & - & - & - & - & - & - & - & - & - & - & - & - & - & - & 2 & 7 \\
\hline Ficus natalensis & 97.1 & 94.3 & 7.1 & - & - & - & - & 30.0 & - & - & 12.9 & - & 51.4 & 5.7 & - & 90.0 & - & - & 25.7 & 35.7 & - & 27.1 & - & - & - & 11 & 1 \\
\hline Ficus ovata & 75.7 & 72.9 & 10.0 & - & - & - & - & - & - & - & - & - & - & - & - & - & - & - & 48.6 & - & - & - & - & - & - & 4 & 5 \\
\hline Ficus sycomorus & 95.7 & 34.3 & - & - & - & - & - & - & - & - & - & - & - & - & - & - & - & - & - & - & - & - & - & - & - & 2 & 7 \\
\hline Gliricidia sepium & 57.1 & & - & - & - & - & - & - & - & - & - & - & $\mid 17.1$ & - & - & 22.9 & - & - & - & - & - & - & - & - & - & 3 & 6 \\
\hline Grevillea robusta & - & 10.0 & 12.9 & - & - & - & - & 2.9 & - & 10.0 & - & - & 8.6 & 32.9 & - & - & - & - & - & - & - & - & - & - & - & 6 & 3 \\
\hline Grewia mollis & - & - & - & - & - & - & - & - & - & - & - & - & 15.7 & - & - & - & - & - & - & - & - & - & - & 5.7 & - & 2 & 7 \\
\hline Jatropha curcas & & - & - & - & - & 40 & - & 32.9 & & - & - & - & - & - & - & - & - & - & - & - & - & 88.6 & - & - & - & 3 & 6 \\
\hline Leucaena leucocephala & 40.0 & - & - & - & - & - & - & - & 10.0 & - & - & - & 8.6 & - & - & 68.6 & - & - & - & - & - & 2.9 & - & - & - & 5 & 4 \\
\hline Maesopsis eminii & - & 14.3 & 25.7 & - & - & - & - & - & - & 71.4 & - & - & - & 75.7 & & - & - & - & - & - & - & - & - & - & - & 4 & 5 \\
\hline Mangifera indica & - & 81.4 & - & - & - & - & - & - & - & 97.1 & - & - & - & - & 100.0 & 20.0 & - & - & - & - & - & - & - & - & - & 4 & 5 \\
\hline Markhamia lutea & - & - & - & - & - & - & - & - & - & 54.3 & - & - & 12.9 & 87.1 & - & - & - & - & - & - & - & 71.4 & - & 5.7 & 80.0 & 6 & 3 \\
\hline Milicia excels & - & - & - & - & - & - & - & - & - & 24.3 & - & - & - & 55.7 & - & - & - & - & - & - & - & - & - & - & - & 2 & 7 \\
\hline Moringa oleifera & - & - & - & - & - & - & - & - & - & - & - & - & - & - & 4.3 & 28.6 & 35.7 & - & - & - & - & - & - & - & - & 3 & 6 \\
\hline Persea americana & - & - & - & - & - & - & - & - & - & 92.9 & - & - & - & - & 100.0 & - & - & - & - & - & - & - & - & - & - & 2 & 7 \\
\hline Pinus caribaea & - & - & - & 4.3 & 1.4 & - & - & - & - & 41.4 & - & - & - & 38.6 & & - & - & - & - & - & - & - & - & - & - & 4 & 5 \\
\hline Psidium guajava & - & - & - & - & - & - & - & - & - & 4.3 & - & - & - & - & 100.0 & - & - & - & - & - & - & - & - & - & - & 2 & 7 \\
\hline Ricinus comminis & - & 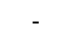 & - & - & - & - & 1.4 & - & - & - & - & . & - & - & - & - & - & - & - & - & - & - & 51.4 & - & - & 2 & 7 \\
\hline Sapindus saponeria & - & 8.6 & - & - & - & - & - & - & - & - & - & 18.6 & - & - & - & - & - & - & - & - & - & - & - & - & - & 2 & 7 \\
\hline Sesbania sesban & 100.0 & - & - & - & - & - & - & - & 50.0 & - & - & - & 15.7 & - & - & 81.4 & - & - & - & 4.3 & - & 17.1 & - & - & - & 6 & 3 \\
\hline Spathodea campanulata & - & 40.0 & 27.1 & - & - & - & - & - & - & - & - & - & - & 64.3 & 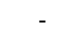 & - & - & - & - & - & - & - & - & - & - & 3 & 6 \\
\hline Syzygium сumini & - & - & - & - & - & - & - & - & - & - & - & - & - & - & 30.0 & - & - & - & - & - & - & - & - & - & - & 1 & 8 \\
\hline Tamarindus indica & - & 45.7 & - & - & - & - & - & - & - & - & - & - & - & - & 64.3 & - & - & - & - & - & - & - & - & - & - & 2 & 7 \\
\hline Vangueria apiculata & - & - & - & - & - & - & - & - & - & - & - & - & - & - & 38.6 & - & - & - & - & - & - & - & - & - & - & 1 & 8 \\
\hline Vernonia amygdalina & - & - & - & - & - & - & - & - & - & - & - & - & 32.9 & - & - & 72.9 & 98.6 & - & - & - & - & 11.4 & - & - & - & 4 & 5 \\
\hline \multicolumn{28}{|l|}{$\%$} \\
\hline $\mathbf{N}$ & 10 & 15 & 8 & 1 & 1 & 1 & 1 & 3 & 3 & 14 & 2 & 1 & 15 & 14 & 12 & 12 & 5 & 2 & 2 & 5 & 1 & 8 & 2 & 2 & 1 & & \\
\hline Rank & 4 & 1 & 5 & 9 & 9 & 9 & 9 & 7 & 7 & 2 & 8 & 9 & 1 & 2 & 3 & 3 & 6 & 8 & 8 & 6 & 9 & 5 & 8 & 8 & 9 & & \\
\hline
\end{tabular}

Key: Functions: $\mathbf{S F}=$ soil fertility, $\mathbf{S D}=$ shade, $\mathbf{W B}=$ wind breakers, $\mathbf{E N}=$ environmental restoration, $\mathbf{R F}=$ making rain, $\mathbf{L M}=$ marking boundaries, $\mathbf{R M}=$ raw materials for industries, $\mathbf{L F}=$ live fence, $\mathbf{S S}=$ soil stabilization; Services: IC=income, $\mathbf{C U}=$ cultural attachment, $\mathbf{G M}=$ traditional games; Products: $\mathbf{F W}=$ firewood, $\mathbf{T M}=$ =timber, $\mathbf{F D}=$ food, $\mathbf{F A}=$ fodder, $\mathbf{M D}=$ medicine, $\mathbf{C H}=$ charcoal, $\mathbf{B C}=$ backcloth and craft, $\mathbf{P F}=$ poles for fencing, $\mathbf{P C}=$ poles for construction, $\mathbf{S C}=$ stakes for climbing crops, $\mathbf{S B}=$ stakes for popping bananas, $\mathbf{S H}=$ =stakes for handles, $\mathbf{S F S}=$ =stakes for debudding bananas. $\mathbf{N}=$ Number of farmers mentioning that specific tree species 


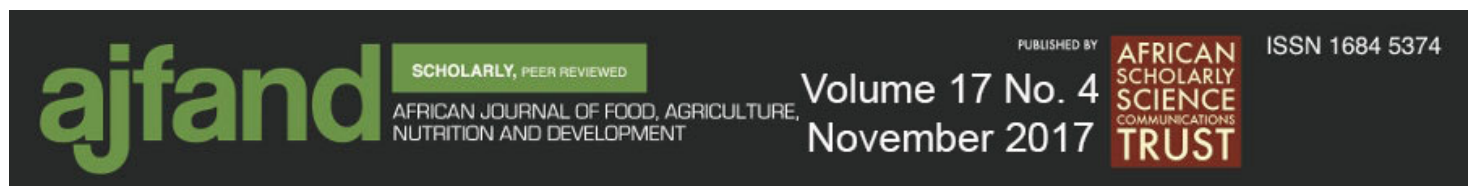

Table 5: Tree/shrub species reported by farmers $(n=70)$ as ' $g o o d$ ' or 'bad' neighbors to bananas in Kiboga district, Uganda (Bold $\geq \mathbf{5 0 \%}$ )

\begin{tabular}{|c|c|c|c|c|c|c|}
\hline \multirow[t]{2}{*}{ Scientific name } & \multirow[t]{2}{*}{ English name } & \multirow{2}{*}{$\begin{array}{l}\text { Local name } \\
\text { (Luganda) }\end{array}$} & \multicolumn{2}{|c|}{ 'Good' } & \multicolumn{2}{|c|}{ 'Bad'" } \\
\hline & & & $\%$ & Rank & $\%$ & Rank \\
\hline Acacia hockii & Wild acacia & Akasaana & - & - & 100.0 & 1 \\
\hline Albizia coriaria & Albizia & Mugavu & 100.0 & 1 & - & - \\
\hline Albizia zygia & West African Albizia & Nongo & 40.0 & 7 & 60.0 & 19 \\
\hline Annona senegalensis & Wild custard apple & Kitaferi & 35.7 & 10 & 64.3 & 16 \\
\hline Antiaris toxicaria & False iroko & Kirundu & 11.4 & 18 & 88.6 & 8 \\
\hline Artocarpus heterophyllus & Jackfruit tree & Fenensi & 1.4 & 24 & 98.6 & 2 \\
\hline Azadirachta indica & Neem tree & Nnimu & 100.0 & 1 & - & - \\
\hline Brachystegia spiciformis & Zebrawood & Musasa & 18.6 & 16 & 81.4 & 10 \\
\hline Calliandra calothyrsus & Calliandra & kaliyandula & 100.0 & 1 & - & - \\
\hline Canarium schweinfurthii & Incense tree & Muwafu & 35.7 & 10 & 64.3 & 16 \\
\hline Carica papaya & Pawpaw/papaya & Mapapaali & 38.6 & 8 & 61.4 & 18 \\
\hline Citrus sinensis & Sweet orange & Mucungwa & 5.7 & 21 & 94.3 & 5 \\
\hline Erythrina abyssinica & Lucy bean tree & jjirikiti & 54.3 & 4 & 45.7 & 22 \\
\hline Eucalyptus grandis & Eucalyptus & Kalitunsi & - & - & 100.0 & 1 \\
\hline Ficus exasperate & Forest sand paper fig & Luwawu & 37.1 & 9 & 62.9 & 17 \\
\hline Ficus mucuso & Fig & Mukunyu & 41.4 & 6 & 58.6 & 20 \\
\hline Ficus natalensis & Natal fig & Mutuba & 95.7 & 2 & 4.3 & 24 \\
\hline Ficus ovata & Fig & Mukokowe & 82.9 & 3 & 17.1 & 23 \\
\hline Ficus sycomorus & Fig mulberry & Kabalira & 100.0 & 1 & - & - \\
\hline Gliricidia sepium & Mouse killer & Muttamese & 41.4 & 6 & 58.6 & 20 \\
\hline Grevillea robusta & Silky oak & Kalivaliyo & 14.3 & 17 & 85.7 & 9 \\
\hline Grewia mollis & - & nkomakoma & 4.3 & 22 & 95.7 & 4 \\
\hline Jatropha curcas & Jatropha & Kilowa & 32.9 & 11 & 67.1 & 15 \\
\hline Leucaena leucocephala & Lead tree & Lucina & 40.0 & 7 & 60.0 & 19 \\
\hline Maesopsis eminii & Umbrella tree & Musizi & 7.1 & 20 & 92.9 & 6 \\
\hline Mangifera indica & Mango & Muyembe & 2.9 & 23 & 97.1 & 3 \\
\hline Markhamia lutea & $\begin{array}{l}\text { Bell Bean Tree, Nile Tulip } \\
\text { Tree }\end{array}$ & Musambya & 8.6 & 19 & 91.4 & 7 \\
\hline Milicia excels & Rock elm & Muvule & 25.7 & 14 & 74.3 & 13 \\
\hline Moringa oleifera & Moringa & Mulinga & 35.7 & 10 & 64.3 & 16 \\
\hline Persea Americana & Avocado pear & Ovakedo & 37.1 & 9 & 62.9 & 17 \\
\hline Pinus caribaea & Caribbean pine & Pine & - & - & 100.0 & 1 \\
\hline Psidium guajava & Guava & Mupeera & 42.9 & 5 & 57.1 & 21 \\
\hline Ricinus comminis & Castor oil plant & Nsogasoga & 37.1 & 9 & 62.9 & 17 \\
\hline Sapindus saponeria & Soap tree & Muyiki & 2.9 & 23 & 97.1 & 3 \\
\hline Sesbania sesban & Sesbania & muzimbandegeya & 100.0 & 1 & - & - \\
\hline Spathodea campanulata & African tulip tree & Kifabakazi & 21.4 & 15 & 78.6 & 11 \\
\hline Syzygium cumini & Black plum & Jambula & 30.0 & 12 & $\mathbf{7 0 . 0}$ & 14 \\
\hline Tamarindus indica & Tamarind tree & mukooge & 27.1 & 13 & 72.9 & 13 \\
\hline Vangueria apiculata & Triangle flowered wild medlar & Mutugunda & 32.9 & 11 & 67.1 & 15 \\
\hline Vernonia amygdalina & Bitter leaf & Mululuza & 37.1 & 9 & 62.9 & 17 \\
\hline
\end{tabular}




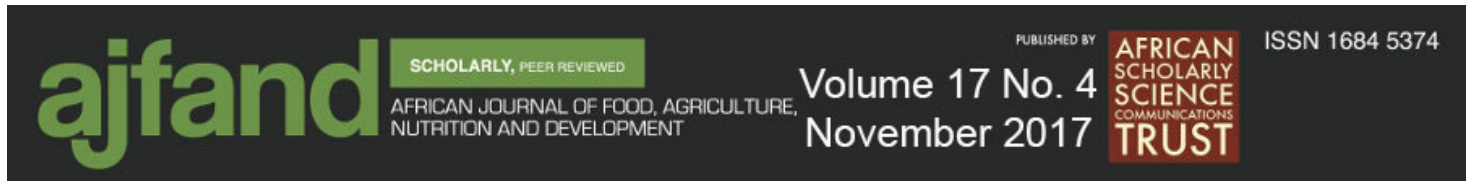

\section{REFERENCES}

1. Kalyebara MR, Ragama PE, Kagezi GH, Kubiriba J, Bagamba F, Nankinga $\mathbf{K C}$ and $\mathbf{W}$ Tushemereirwe Economic Importance of the Banana Bacterial Wilt in Uganda. Afr. Crop Sci. J. 2006; 14 (2): 93-103.

2. Gold CS, Wendt J, De Waele D, Ssali H and WK Tushemereirwe The Contribution of Soil Quality to Yield and Its Relationship with Other Factors in Uganda. A research paper. 2006.

3. Van Asten PJA, Wairegi LWI, Mukasa D and NO Uringi Agronomic and Economic Benefits of Coffee-Banana Intercropping in Uganda's Smallholder Farming Systems Agric Syst. 2011; 104 (4): 326-334.

4. Van Asten PJA, Gold CS, Okech SH, Gaidashova SV, Tushemereirwe WK and D De Waele Soil Quality Problems in East African Banana Systems and their relation with other yield loss factors. InfoMusa 2004; 13 (2): 20-25.

5. Van Asten P, Wanyama I, Mukasa D, Nansamba R, Kisaakye J, Sserubiri I,Bongers $\mathbf{G}$ and $\mathbf{L}$ Jassogne Mapping and Evaluating Improved Intercrop and Soil Management Options for Ugandan Coffee Farmers. A Technical Report. IITA. 2012.

6. Nyombi K Towards Sustainable Highland Banana Production in Uganda $A f r$. $J$. F. Agric. Nutr. and Dev. 2013; 13 (2): 7544-61.

7. Gold CS, Karamura E, Kiggundu A, Bagamba F and AMK Abera Geographic Shifts in Highland Cooking Banana (Musa Spp., Group AAA-EA) Production in Uganda. Inter. J. Sust. Dev. and Wor. Ecol. 1999; 6 (1): 45-59.

8. Sseguya H, Semana AR and MA Bekunda Soil Fertility Management In The Banana-Based Agriculture Of Central Uganda: Farmers Constraints And Opinions. Afr Crop Sci. J. 1999; 7 (4): 559-67.

9. Oduol PA and JRW Aluma The Banana (Musa Spp.) - Coffee Robusta: Traditional Agroforestry System of Uganda Agrofor. Syst. 1990; 11 (3): 213-26.

10. Nyombi K, Esser KB and JYK Zake Efforts by Small-Scale Farmers to Maintain Soil Fertility and Their Impacts on Soil Properties, Luwero District, Uganda. J. Sust. Agriculture 2006; 27 (4): 5-23.

11. Beer J, Muschler R, Kass D and E Somarriba Shade Management in Coffee and Cacao Plantations. Agrofor. Syst. 1998; 38: 139-64.

12. Muzoora A, Turyahabwe $\mathbf{N}$ and JGM Majaliwa Validation of Farmer Perceived Soil Fertility Improving Tree Species in Agropastoral Communities of Bushenyi District. Intern. J. Agron. 2011; 2011: 1-10.

13. Nathan I, Soren $\mathbf{L}$ and I Theilade The Importance of Local Knowledge and Interdisciplinary Research. J. Transdisciplinary Environ. Studies 2007; 6 (1): 1-5. 


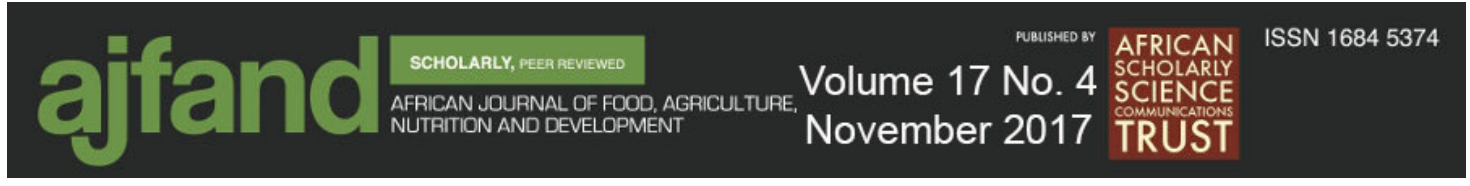

14. KDLG. Subcounty Development Programme. Implementation of the Community Information system (CIS). Kiboga District Local Government Report Based on CIS Summary Results 2011.

15. KDLG. Kiboga District Local Government Five-Year District Development Plan (2010/11-2014/15) 2012.

16. Mpiira S, Staver C, Kagezi GH, Wesiga J, Nakyeyune C, Ssebulime G, Kabirizi J, Nowakunda K, Karamura $\mathbf{E}$ and WK Tushemereirwe The Use of Trees and Shrubs to Improve Banana Productivity and Production in Central Uganda: An Analysis of the Current Situation. In: Banana Systems in the Humid Highlands of Sub-Saharan Africa: Enhancing Resilience and Productivity, Blomme G, Van Asten P and B Vanlauwe (Eds.). 2013; 150-57.

17. Nantale G, Kakudidi EK, Karamura DA, Karamura E and G Soka Scientific Basis for Banana Cultivar Proportions on-Farm in East Africa. Afr. Crop Sci. J. 2008; 16 (1): 41-49.

18. SAS, Institute SAS/STAT Software: Version 9.2, Cary, NC: SAS Institute Inc. 2008.

19. Kiyingi I, and S Gwali Productivity and Profitability of Robusta Coffee Agroforestry Systems in Central Uganda. Ug. J. Agric. Sci 2012; 13 (1): 85-93.

20. Isabirye BE Role of Agro-Ecosystems in Conservation of Tree Species in the Lake Victoria Catchment : A Case Study of Baitambogwe Sub-County, Mayuge District.MSc. Thesis. Makerere University, Kampala, Uganda 2009.

21. Dold C, Staver C, Siles P, Bustamante O, Lichtemberg PDSF and J Burkhardt Improving Banana Production in Coffee Agroforestry Systems in Central America. In: World Food System - A Contribution from Europe. 2010.

22. Edmeades S, Smale $\mathbf{M}$ and D Karamura Biodiversity of Bananas on Farms in Uganda Promising Crop Biotechnologies for Smallholder Farmers in East Africa: Bananas and Maize. Brief 24. 2006.

23. Ouma G Intercropping and Its Application to Banana Production in East Africa : A Review. J. Plant Breed. and Crop Sci. 2009; 1 (2): 13-15.

24. D, Assefa F, Nemomissa $\mathbf{S}$ and $\mathbf{U}$ Granhall Socioeconomic Benefits of Shade Trees in Coffee Production Systems in Bonga and Yayu- Hurumu Districts Southwestern Ethiopia: Farmers' Perceptions. Ethio. J. Educ. \& Sc., 2011; 1: $39-56$.

25. Kalanzi F and S Nansereko. Exploration of Farmers Tree Species Selection for Coffee Agroforestry in Bukomansimbi District of Uganda. Intern. J. Res. on Land-Use Sust. 2014; 1: 9-16.

26. Tabuti JRS Important Woody Plant Species, their Management and Conservation Status in Balawoli Sub-County, Uganda. Ethnobot. Res. and Applic. 2012; 10: 269-86. 


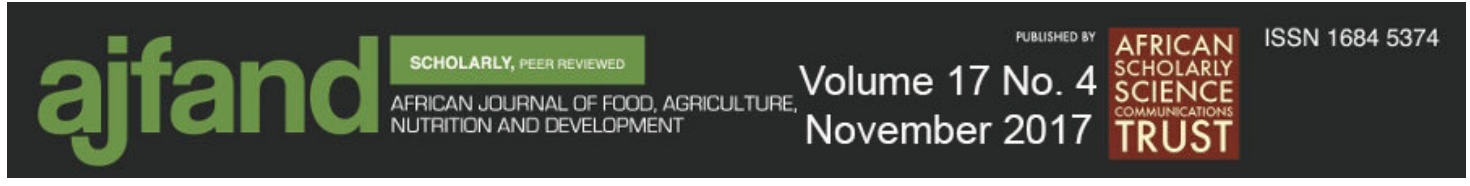

27. Charles RL, Munishi PKT and EF Nzunda Agroforestry as Adaptation Strategy under Climate Change in Mwanga District, Kilimanjaro, Tanzania. Intern. J. of Environ. Prot. 2013;3 (11): 29-38.

28. Meaza $\mathbf{H}$ and B Demssie Managing Fragile Homestead Trees to Improve Livelihoods of Land-Poor Farmers in the Northern Highlands of Ethiopia Sing. J. of Trop. Geog. 2015; 36: 57-66.

29. Nyamukuru A, Nabatanzi A, Mpiira S, and JRS Tabuti Locally Preferred Woody Species and Their Management in Kiruhura and Arua Districts, Uganda. Ethnobot. Res. and Applic. 2015; 14: 049.

30. Tabuti JRS, Dhillion SS and KA Lye Firewood Use in Bulamogi County, Uganda: Species Selection, Harvesting and Consumption Patterns. Biom. and Bioene. 2003; 25 (6): 581-96.

31. Agea JG, Kirangwa D, Waiswa D and CA Okia Household Firewood Consumption and Its Dynamics in Kalisizo Sub-County, Central Uganda. Ethnobot. Leaflets 2010; 14: 841-55.

32. Zziwa A, Bukenya M, Sseremba OE and RK Kyeyune Non-Traditional Tree Species Used in the Furniture Industry in Masaka District, Central Uganda. Ug. J. Agric. Scie. 2006; 12 (1): 57-64.

33. Tabuti JRS and BB Mugula The Ethnobotany and Ecological Status of Albizia Coriaria Welw. Ex Oliv. in Budondo Sub-County, Eastern Uganda. Afri. J. of Ecol. 2007; 45 (SUPPL. 3): 126-29.

34. Dumont ES, Gnahoua GM, Ohouo L, Sinclair FL, Vaast P, Dumont ES and GM Gnahoua Farmers in Côte d'Ivoire Value Integrating Tree Diversity in Cocoa for the Provision of Ecosystem Services Agrofor. Syst. 2014; 88 (6): 10471066.

35. Valencia V, West P, Sterling EJ, Garcia-Barrios L and S Naeem The Use of Farmers Knowledge in Coffee Agroforestry Management: Implications for the Conservation of Tree Biodiversity Ecosphere 2015; 6: 1-17.

36. Albertin A and PKR Nair Farmers' Perspectives on the Role of Shade Trees in Coffee Production Systems: An Assessment from the Nicoya Peninsula, Costa Rica. Human Ecology 2004; 32 (4): 443-63.

37. Anglaaere LCN, Cobbina J, Sinclair FL and MA McDonald The Effect of Land Use Systems on Tree Diversity: Farmer Preference and Species Composition of Cocoa-Based Agroecosystems in Ghana. Agrofor. Syst. 2011; 81 (3): 249-65. 